\title{
Raphael Baldaya and Fernando Pessoa: The Search for a Common Universal Source of Inquiry between Symbology and Poetry
}

\author{
Paulo Nuno Martins* \\ CTEC-Universidade Fernando Pessoa do Porto, CIUHCT-Universidade Nova de Lisboa
}

*Corresponding Author:Paulo Nuno Martins, CTEC-Universidade Fernando Pessoa do Porto, CIUHCTUniversidade Nova de Lisboa

\begin{abstract}
This article seeks to contribute to the study of the complementary facets that we find in the astrological symbolism of Raphael Baldaya's work, on the one hand, and the "initiatic" poetry of Fernando Pessoa's Mensagem, on the other hand.

We will see how these facets, although different in their effective study, are in fact interconnected and influence each other in Fernando Pessoa's life and work, namely in the way he expresses his poetry, for which he is widely known.

Key words:Raphael Baldaya and astrological symbolism, The "Initiation" in Fernando Pessoa, Psychohistorical framework of the work Mensagem, Perspectives on the symbolism of the "Rose" and the "Cross" in the bookMensagem.
\end{abstract}

\section{INTRODUCTION}

All creation, be it a literary work or scientific theory, has its origins in symbolism and mythology, to which all cultures are linked, particularly in an unconscious way. However, at a certain point in history, there was a separation between the apprehension of the reality obtained rationally ("science") and the processes obtained through intuition and symbolism. One of the exceptions to the previous perspective is the multifaceted personality of Fernando Pessoa [1] who sought to "reconcile" these two sides of the human being, through astrological symbolism, evidenced by the works of Raphael Baldaya, and his facet as a poet, expressed in his work "initiatory" Mensagem, which deals with history and the Portuguese Soul [2]. In fact, Fernando Pessoa studied several spiritual traditions, with a particular interest in the Portuguese mythical-spiritual tradition ${ }^{1}$, having a prophetic vision of Portugal, where the "Sebastianian" myth should be realized in the future V Spiritual Empire [3].

\section{RAPHAEl BALDAYA AND THE CONCISE History OF WESTERn ASTROLOGY}

The study and practice of astrology was part of Fernando Pessoa's work, under the name of Raphael Baldaya. Astrology is a way that might help to "see" beyond appearances, and from there it is often linked to the study of the themes of "alchemy" and "initiation" that also interested Fernando Pessoa, and that will therefore be covered in the following sections. Thus, we will present the historical framework of this interest, briefly referring to the main milestones in the history of Western astrology [4].

It is supposed that it started in ancient Mesopotamia, through the Chaldean tribe (c. 4000 BC) that became part of the Babylonian and Assyrian Empires, where the writing of an emblematic text about the omens astrology (without zodiac), gave rise to worldly astrology and natal astrology - named by EnumaAnu Enlil (c.1950 BC). Another text on elective astrology was written, called the Table of Venus of Ammisaduqa (c.1700 B.C.). To the first manuscript was added the "zodiacal signs" (c. 500 $\mathrm{BC}$ ), after the domination of Mesopotamia by the Persian people, who prepared the "Astronomical Diaries". However, when Alexander the Great conquered Mesopotamia and then advanced to the region of Asia Minor, there was contact with Eastern culture, namely with sidereal or Vedic astrology (it is assumed to have originated in the Indus Valley civilization, around $3000 \mathrm{BC}$ ). The difference between the way of calculating the position of celestial bodies, in Vedic astrology and tropical or Western astrology, is called "Ayanamsa" (from Sanskrit ayana or "movement" and amshaor "portion"). 
On the other hand, during the Roman Empire, it is worth mentioning the name of Ptolemy - author of the astronomical work called by Almagest ("The Great Treaty") - who together with Hipparchus (who discovered the "Precession of the Equinoxes" ) proposed the "Geocentric model". Ptolemy also wrote the work of astrology called Tetrabiblos which is a compilation of all astrological knowledge of this time and in which he divides the study of astrology into two major areas: worldly or nation astrology (accepted by the Catholic Church), which studies life collective, such as agriculture, natural phenomena, and on the other hand, natal astrology (rejected by the Catholic Church), which studies man as an individual being inserted in the cosmos. Also worth mentioning is the name Julius FirmicusMaternus, who translated some astrological texts, some of which were read by Pope Silvestre II, before there was contact with Islamic culture, namely with Albumashar (from the Baghdad School) and Albiruni, who did the Arabic translation of the Ptolemaic texts.

During the Medieval Age, astrology was practiced in Cortes and taught at European Universities such as the University of Salamanca (13th century). In the 11th century, Rogério de Hereford wrote The Book of the Astronomy Division and its Four Parts, in which Natal, Mundane, Horary (answers to specific questions) and Elective (favorable time to start an event) are named as the four parts of astrology. It should be noted that Raphael Baldaya came to dedicate himself essentially to the study of the areas of Natal astrology - in the elaboration of its heteronyms - and of Elective astrology - in the study of the Horoscope of Portugal - as we will see in the next chapter.

In the 16th century, during the Renaissance, we have to mention the names of Kepler (assistant to the astronomer Tycho Brahe) - the author of the three laws of planetary motion - for being an excellent astrologer, while Galileo Galilei, defender of the empirical method and considered the father of "Modern Science", was an astrologer of Médicis. These two scientists contributed to the recognition of the "Heliocentric model". During the 17th century, Newton, the author of the laws of "Classical Mechanics", was an alchemist who had books on astrology in his library. In the 18th century, a reference to William Lilly as a practitioner of Horary astrology was made. However, from the end of the 17th century until the 19th century, there was a decline in the "quality" of astrological practice, which was restricted to periodicals (newspapers, magazines).However, in the early 20th century, Alan Leo or William Frederik Alan sought to make astrology a "science of self-knowledge" again, having studied Vedic astrology in India (referred to as "Jyotish", that is, "knowledge, light"). Alan Leo taught several students at the Theosophical Society in London, including Charles Carter, who together with Dane Rudhyar, founded the Faculty of Astrological Studies in 1948. John Addey, the author of the "Theory of Harmonics", whose study is fundamental for a deep understanding of astrology, should be mentioned.

Thus, since the middle of the 20th century, there have been several astrologers who have sought to study the relationship between the study of the "psyche" and astrological symbolism. It should be noted that Jung ${ }^{3}$ argued that individuals, like nations, can be described psychologically, through symbols. Thus, in the study of the psyche-the total sum of all "conscious processes" (include the "Ego") and "unconscious processes" (including the "personal unconscious" and the "collective unconscious") - different individuals (distinct "Egos") interconnect through the "Collective unconscious"which is where mythological symbols originate. There are patterns or archetypes that result from this "collective memory" and that are described through poetry. For example, in the work Mensagem, Fernando Pessoa, in the poem Ulisses, mentioned: «The mytho is the nothingness that is everything» ${ }^{4}$, being Ulissesthe mythological hero of Homer's Odyssey, who would have founded the city of Olisipo (Lisbon). The "Personal Unconscious", on the other hand, is characteristic of a certain individual and results from repressed (unpleasant, painful) experiences. In this case, Jung [5] mentions in his work entitled Poesia e Psicologia: «The poetic, authentic experience emerges from deep, healthy and beneficial regions of the soul, pre-existing to the segregation of individual consciences, and which, from that collective lap, followed your painful steps. It springs from those regions where all beings still vibrate, in unison, $\ldots \nu^{5}$.

Thus, some perspectives consider that the elaboration of the horoscopes of the main heteronyms of Fernando Pessoa (Alberto Cairo, Ricardo Reis, Álvaro de Campos) are the multi-facets of his personality (the "I") when the poet sought to access the his deeper side of his personality. In this sense, Celeste Malpique [6] investigated the way Fernando Pessoa's heteronyms are organized around this Self. 
It should be added that Carl Jung, ${ }^{6}$, in his activity as a psychoanalyst, wrote about astrology: «Astrology consists of symbolic configurations of the collective unconscious, which is the main subject of psychology; the planets are gods, symbols of the powers of the unconscious...» ${ }^{7}$.

$\mathrm{Jung}^{8}$ also mentioned the importance of self-awareness in the achievement of individual freedom, having written: «... what we are not consciously in contact with appears as a destination.», that is, Jung considered that the psyche (interior) and the cosmos (outer) care "interconnected" through "significant coincidences", whose phenomenon is called by "Synchronicity".

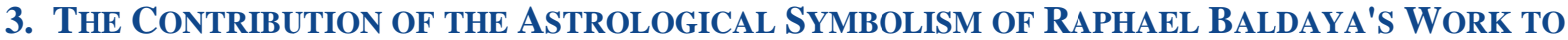 THE WORK MENSAGEM FROM FERNANDO PESSOA: A PERSPECTIVE}

There are several research works on Fernando Pessoa's interest in symbolism, such as those by Carlos Moisés [7]: «I base myself on the fact that Pessoa devoted much of his effort to the study of Rosicrucianism, Theosophy, Buddhism, Kabbalah; wrote a number of texts on these doctrines; and, although he did not become orthodox of any of them, at least he used the respective symbologies not only in "Mensagem" but in other works ${ }^{10}$.

In this regard, Raphael Baldaya was the heteronym of Fernando Pessoa who used astrological symbolism to "interpret" the personality characteristics of each of Fernando Pessoa's heteronyms (Alberto Caeiro, Ricardo Reis, Álvaro de Campos) [8]. It should be noted that, in the astrologer's private library, we find some emblematic books on this theme, such as "The Art of Synthesis" by Alan Leo [9], with whom Fernando Pessoa corresponded.

In 1916, Raphael Baldaya [10] outlined, in addition to Fernando Pessoa's "Personal Horoscope", the "Horoscope of Portugal" with the "Midheaven" in Pisces (the zodiac sign that is at the zenith at the time of birth), symbolically indicating the Mission of Portugal, which was marked in the Mensagem, through the description of the "Discoveries", while the "Ascendant" in Cancer (the zodiac sign that rises on the horizon at the time of birth), symbolically represents the Portuguese external Aspect, expressed in the bookMensagem, as nostalgic for the past. It should be added that there have been several studies on the "Astrological Map of Portugal". However, in historical terms, the "birth of Portugal" had several phases that included the government of the Portucalense County by D. Henrique, the regency of D.Teresa de Leão, the government by D. AfonsoHenriques, the signature of the Treaty of Zamora. This is the reason why there are several possibilities for the "initiatory birth" of Portugal.

Thus, the "Symbolic Map of Portugal", erected by Raphael Baldaya, marks only the "astrological houses", but without the position of the planets, having been progressed to several important dates in the History of Portugal, some of which are referred to in the work Mensagem by Fernando Pessoa. In this sense, the "Soul of Portugal" or the "Spiritual Birth" (the Soul is seen by the Ascending sign and its ruler) ${ }^{11}$ is governed symbolically by the planet Neptune that represents the Portuguese spiritual experience, referred to in Fernando Pessoa's Mensagem, as the future "V Spiritual Empire".

\section{The "Initiation" in FERnANdo PeSsoa: An Essay}

The word "Initiation" (from the Latin "initatio") is a term composed of two words from the Latin, respectively "In" (to enter) and "Ire" (To go, to walk); that is, "entrance into". Regarding the theme of "initiation", Fernando Pessoa [11] wrote: «What is called "initiation" is of three kinds: There is, first, and at the lowest level, exoteric initiation, ... it is the initiation given to those who prepared for it if ... There is, afterwards, the esoteric initiation ... it has to be sought by the disciple ... There is, finally, the divine initiation. In the latter, they do not give it nor isitexoteric or minor esoteric ... it comes directly, and above all of them, from the same hands, of what we call God. The supreme type of this initiation is that of Jesus... ${ }^{12}$.Thus, in the first type of "initiation" the human being experiences suffering and happiness; that is, the "life experience" of the "I". In the second type of "initiation" it is that which is transmitted through symbolic language and aims at increasing the awareness of the "personality" about the "Self or Soul". The third type is that of "Divine Initiation" which is transmitted "inwardly" by a Spiritual Master, and whose steps are described, for example, in Voice of Silence [12], an occult book that was translated into Portuguese by Fernando Pessoa. Some perspectives consider the life of Jesus as symbolically representative of the "Divine initiations" 13 , distributed over "five stages". 
These represent the entrance to the "Kingdom of the Soul" - designated by "Birth"14,15 - and then to the "Kingdom of the Spirit" - designated by "Baptism"16. These are deepened through "access" to the Mysteries of Life - referred to as "Transfiguration on the Mountain" - and to the Mysteries of Death referred to as "Passion, Death and Resurrection". These steps are carried out according to the aphorism: «When the disciple is ready, the Master appears» ${ }^{17}$.This "trip" of the Soul is described by Fernando Pessoa in several poems, namely in Do Vale à Montanha, Á sombra do Monte Abiegno, Os Passos da Cruz, Além-Deus, whose essence of the theme has been an area of research carried out by some scholars on this subject [13]. Fernando Pessoa's perspective on the "initiation" theme is described particularly in the poem Initiation [14]: «... The body is the shadow of the robes/Night comes, which is death,/And the shadow ended up not being/You go in the night, just cut it out,/Just like you unintentionally./.../Then Archangels of the Road / Undress and leave yourself naked. The shadow of your garments/He remained among us in Luck./He is not dead, among cypress trees./Neophyte, there is no death. $»^{18}$.

The poet adds on the objective of "initiation" [15]: «... is that this visible world in which we live is a symbol and a shadow, that this life that we know through the senses is a death and a sleep, or, for other reasons words, that what we see is an illusion. Initiation is the dissipation - a gradual, partial dissipation - of that illusion ... $\gg^{19}$.In this "initiation" theme Fernando Pessoa refers to the need to purify the vehicles of the personality (concrete mental, emotional and physical); that is, to the "stripping of the clothes" of the personality, so that the Soul can receive the Mensagem (Message). To this end, he indicates in his work, the five qualities necessary to understand it: «The understanding of symbols and (symbolic) rituals requires the interpreter to possess five qualities or conditions, without which the symbols will be killed for him, and he a dead one for them. The first is sympathy ... for the symbol you intend to interpret ... The second is intuition ..., that kind of understanding with which you feel what is beyond the symbol, without seeing it ... The third is the intelligence. To relate at the top what is in accordance with the relationship below ... The fourth is understanding, the knowledge of other matters that allow the symbol to be illuminated by various lights, relating to several other symbols ... The fifth is less definable. I will say, perhaps, speaking to some, which is grace, speaking to others that it is the hand of the Higher Unknown, speaking to others that it is the Knowledge and Conversation of the Holy Guardian Angel, understanding each of these things as those who understand them use speaking or writing $»^{20}$. George Lind [16] contextualizes the text previously mentioned: «You received the light of the Order in which you were blind. You will now receive your Robe that you were naked. Now that you have received the "Light and the Robe" of the Order, you will be reminded that you are lacking the Order's Shelter... However, the Lair will give you where you have light even though there is no light from outside, where you have clothes, because you have shelter, even if you are naked in the lair ... Blind, naked and poor you entered life. Blind, naked and poor, you will enter death ... This is the truth: the understanding is with you, as well as governing it as you should $»^{21}$.

On the other hand, as to Fernando Pessoa's own "initiation" process, Yvette Centeno wrote [17]: «Initiative Position: Initiated, by direct communication from Master to Disciple, in the three minor degrees of the (apparently extinct) Templar Order of Portugal ... $»^{22}$.

Then, Fernando Pessoa mentions in a letter to Adolfo Casais Monteiro [18]: «... Ask me if I believe in the occult ... I believe in the existence of worlds superior to ours and of inhabitants of those worlds, in experiences of different degrees of spirituality, using themselves until we reach a Supreme Being... but, according to our spiritual attunement, we can communicate with higher and higher beings. There are three paths to the occult: the magical path ..., the mystical path ..., and the alchemical path .... As for "initiation" or not, I can tell you just this, that I don't know if it responds to your question: I do not belong to the Initiatic Order at all. The quote, epigraph to my poem Eros and Psyche, from an excerpt (translated, because the Ritual is in Latin) of the Ritual of the Third Degree of the Templar Order of Portugal, simply indicates what it is that I was allowed to leaf through the Rituals of the three first degrees of that Order, extinct, ... $»^{23}$.

Still, regarding the "occult" theme, Fernando Pessoa mentioned, in Rituais[19]: «My brother, you received the Word./P - I opened the atrium, Master ofAtrio, and let the neophyte appear between the two columns./P - Now that you have been given the light, you will lower your eyes to the ground./P Where do you come from?/P - What do you believe in?/P - Who arrives, Master of the Court?/Lord, 
who are you? Heaven and earth, and that you are life and death!/See, my brother, this mosaic floor; ${ }^{24}$. Finally, in a letter written to Aunt Anica in 1916, Fernando Pessoa complemented the description of his own "initiation process" [20]: «The fact is as follows. Then by the end of March (if I'm not mistaken), I started to be a medium. Imagine! I, who (as you will recall) was a delaying element in the semi-spiritual sessions we were doing, suddenly started with automatic writing. I was at home once, at night, having come from "Brasileira", when I felt like literally taking a pen and putting it on paper. Of course, I later realized that it was that impulse. At the moment, I did not notice the fact, I took it as the fact, natural in those who are distracted, to pick up a pen to make doodles.... $»^{25}$. In this regard, Dalila Costa completed this study, referring to [21]: «Between the three paths, poetic, initiatic and contemplative, there will be no opposition: they will be different paths leading to the same single central point ... it appears that Fernando Pessoa he accomplished the first ... but he failed in the initiatic, where from a certain moment it came to a halt, stagnation and dissolution ... $\mathrm{He}$ lost himself in the foreground, the psychic, before he could reach the goal - liberation, which would it happen on the next level, the spiritual? ... $»^{26}$. This perspective is supported by André Coyne who wrote [22]: «... Pessoa, without a doubt, never acceded to the "second birth"of the initiatory revelation, nor did he truly acquire one of those"effective knowledge"...»"

\section{Fernando Pessoa's Mensagemand Indian Philosophies: A SynOPSiS}

The study carried out in Theosophy ${ }^{28}$ on the process of "mystical marriage between the Moon and the Sun" (between the Personality and the Soul, and the Soul with the Spirit), according to the author of this article, is one of the keys to the "initiatory" approach to Fernando Pessoa's Mensagem [23]. In this work, published shortly before the poet's death, Fernando Pessoa highlights this "inner process" of transformation that took place throughout his life, where the influence of Indian philosophies is visible [24].

These defend the interdependence between the Conscious One and the conscious being who chooses to manifest one "potentia" or possibility which determinesif the work will be worldly or spiritual ${ }^{29}$. In this regard, Fernando Pessoa wrote in the verses of the Mensagem: «God wants, $/ »^{30}$ is the One Consciousness, «man dreams, $/ \gg^{31}$ is the conscious subject who chooses from among possibilities, while «the work is born./» $»^{32}$ is the manifestation of the work that exists in "potentia".

It should be added that for the manifestation of the spiritual work, symbolized by the "V Spiritual Empire", it is necessary for the neophyte to go through the difficult stages of "initiation", previously mentioned by Fernando Pessoa. In this sense, the poet wondered, during the writing of the work Mensagem: «Was it worth it? Everything is worth it/If the Soul is not small./» $»^{33}$, giving the perspective that all the effort and suffering that went through was worth it, according to the purpose of the Portuguese Soul [25].

On the other hand, in the process of creating the previous verses of the Mensagem, the symbolism of the mantra $\mathrm{OM}^{34}$ is also present, conveyed by the Indian philosophies and by Theosophy, namely in the book The Voice of Silence, as Fernando Pessoa [26] mentioned in the epigraph of Mensagem the term "Signum" or "sign".

This can be understood in "various levels of consciousness"35, one of which is identical to the Christian symbol of "Word": "In the beginning, the Word already existed, and the Word was with God, and the Word was God, Everything began to exist through Him,... .and the Word became man and dwelt among us... $»^{36}$, according to St. John ${ }^{37}$.

\section{Psycho-Historical Framework of the Work Mensagem: A Perspective}

In symbolic terms, the creation of the literary and "initiatic" work Mensagem is characterized by 44 poems (symbolic number of the completion of the work), distributed by the "Brasão" (symbol of the element "Earth" and "Foundation of the kingdom"), "Mar Português" (symbol of the "Water "element characteristic of the

"Portuguese Maritime Discoveries"), "Encoberto"(symbol of the "Fire"element of "death and renewal", and of the "Air"element symbol of the manifestation of the V Spiritual Empire) [27].

In historical terms, the work Mensagem, finished by Fernando Pessoa [28], on 1st December 1934 (commemoration of the Portuguese Restoration of Independence in 1640), was carried out in the 
1930s, at the same time as the formalization of Quantum Mechanics. The symbol was the privileged instrument for the description of the visible world, both in the literary work Mensagem and in the scientific creation of Quantum Mechanics. Historically, the 1930s called into question the uniformity of interpretation of reality, namely due to the effects of the "Great Depression" (from the New York Stock Exchange, in 1929) and the beginning of the Second World War (1939-1945), being therefore considered, by some historians, as the worst decade of the 20th century ${ }^{38}$. However, it was highlighted the cosmopolitanism defended by Fernando Pessoa, in the praise of a "race" (the "human race"), with different cultural realities [29].

Currently, some compare the effects of this crisis of the last century, with those of the current Covid19 pandemic which has had an equally harmful effect on the public and the economy of various nations. However, it has promoted the "unity" of the human race around the same objective: the cure of the disease, while looking for the economic stability of the people.

On the other hand, the symbolism of "uncertainty" present in the "collective unconscious" of the 30 s, was also presented in the science of that time, namely through the "Principle of Uncertainty" of Quantum Mechanics ("it is not possible to determine simultaneously, with equal precision, the position and the linear moment of the quantum particle"), which was formulated by Werner Heinsenberg, in 1927. In turn, this symbolism of "uncertainty" is also referred to in the last poem of the Mensagem, called by Nevoeiro[30], which can be read as a symbol for "something that ends in the collective Unconscious". In fact, this poem belongs to the part called "Encoberto", which contains "Os Tempos". Let us see the symbolism of the verses of the poem Nevoeiro [31]: «... Nobody knows what it wants./Nobody knows what soul it has,/ Neither what is bad nor what is good./...» ${ }^{39}$, which can be interpreted as a crisis of society's values. Further on, Fernando Pessoa stated that: «What distant elderly woman cries?) / ... ${ }^{40}$ that calls for change, and for a new time. The end of the glorious Empire is described in: «Everything is uncertain and final./Everything is dispersed, nothing is whole./Ó Portugal, today you are fog... $\rangle^{41}$, which can be interpreted as the prelude to the manifestation of the future "V Spiritual Empire", which is referred to on the back: «It's the Hour! ... »"

In historical terms, the Mensagem, describing Portugal's glorious past, seeks to find a meaning for the decadence that Portugal had reached. In this sense, Fernando Pessoa argued that the country should "regenerate", as "a spiritual empire" (the "V Empire") was about to arrive, where Portugal should carry out its spiritual mission on Earth [32]. In this sense, the poet has chosen to name his work, not that of Portugal (a country that the poet considered to be in a decline of values) ${ }^{43}$, but that of Mensagem $^{44}$. Thus, the work "initiatory" Mensagem begins with the title: «Benedictus Dominus Deus Noster Qui DeditNobisSignum» ("Blessed be the Lord, our God, who has given us a sign"), as a way of giving thanks for the revelation of the symbols that promote "life change", namely the "Rose" and the "Cross" [33]. In fact, the symbols used in "initiation" are ways to access "superior truths" to rational intelligence, and which may justify the interest that the complementary facets of Raphael Baldaya and Fernando Pessoa showed in their work.

In this regard, it should be noted that during the "initiation process", the symbol of the "Rose at the center of the Cross" constitutes for Fernando Pessoa, a factor of hope for the new stage of life, described in the verses of the Mensagem: «What a symbol fecund/ Come at the dawn of anxiety?/On the Dead Cross of the World/Life, which is the Rose./... On the Cross, which is the Destination/ ... /The Rose of the Shrouded.» ${ }^{45}$. This mystique about the symbolism of the Rose is transversal to several cultures. For example, in Eastern culture, namely in the Hindu tradition ${ }^{46}$, the goddess Lakshmi (one of its facets is that of Divine mother) was born of a Rose, symbol of spiritual Beauty. On the other hand, since the 17th century, in Western culture, the Rosecrucians [34] attribute to Rosa the symbolism of the Secret and Mystery of Life. This theme was expressed in the panel O Milagre das $\operatorname{Rosas}^{47}$ ("The Miracle of Roses") by Lima de Freitas, as an allusion to Queen Saint Isabel (promoter of the cult of the Holy Spirit), this symbol being also associated with the Virgin Mary or Divine mother, as an icon of Christianity.It should be added that this same symbolism is present in the Apparitions of Our Lady of Fátima ${ }^{48}$ in 1917 in Portugal.

For its part, the "Cross of Christ" has been associated with the Easter symbolism of the Love of Jesus, whose Message calls all human beings "death for life". Thus, the third part of the Mensagem, by Fernando Pessoa, called "Encoberto", can be interpreted as the Human Being who went through the 
"initiation process of death for life" to manifest the "V Spiritual Empire". This spiritual symbolism is also transversal to different cultures. For example, it is present in Indian spirituality, namely in Bhagavad-Gita ${ }^{49}$ (part of the epic Mahabharata), and which deals with the dialogue between the Love aspect of the Divine and his disciple, who refers to Him as "Hero of the Great Arms" whose expression fits the Pascal symbolism of the Christian culture.

\section{CONCLUSION}

Fernando Pessoa's studies on Hermetic History and Philosophy [35], normally linked to the themes of Astrology, Kabbalah, Hermetism, Gnosis, Alchemy, Esoterism [36], may contribute to the transdisciplinary reading of reality, namely on the themes of Life and Love, Death and Initiation [37]. In this regard, reference is made to the words of Eduardo Lourenço [38]: «Occult poetry covers the entire space of Pessoa's life and work,... The occult view allows the Person to positively integrate the par-realizing obstacle, the Death,... as supreme transparency and supreme rest... $\rangle^{50}$. Thus, we found that the study of the complementary facets of Fernando Pessoa, as an astrologer and poet, requires constant investigation in various areas of knowledge [39], some of which were addressed in this article, with the aim of making the Human Being "free" [40].

\section{REFERENCES}

[1] Pais, Amélia. 1996.Para Compreender Fernando Pessoa.Porto: Areal Editores.

[2] Lima, Isabel. 2011. "Da vida à obra", in Fernando Pessoa, Mensagem(Col. Klássicos), Lisboa.

[3] deAlmeida, Onésimo. 1987. Pessoa, Portugal e o Futuro. Lisboa: Editora Gradiva.

[4] Baigent, Michael e Campion, Nicholas e Harvey, Charles. 1995. Mundane Astrology. New York: HarperCollins Publishers.

[5] Jung, Carl. 1979. Poesia e Psicologia. Torino: Biblioteca BollatiBoringhieri.

[6] Malpique, Celeste. 2012. Fernando em Pessoa: Ensaios de Reflexão Psicanalítica. Lisboa: Edições Fenda.

[7] Moisés, Carlos. 1996. Roteiros de Leitura: Mensagem. Lisboa: Editorial Ática.

[8] Pizarro, Jerónimo e Cardoso, Paulo. 2011. Cartas Astrológicas de Fernando Pessoa.Lisboa: Bertrand Editora.

[9] Leo, Alan. 2010. The Art of Synthesis. Montana: Kessinger Publishing, LLC.

[10] Cardoso, Paulo. 1991. Mar Portuguez e a simbólica da Torre de Belém.Lisboa: Editorial Estampa.

[11] Pessoa, Fernando. 1989. A Procura da Verdade Oculta - Textos filosóficos e esotéricos. Lisboa: Publicações Europa-América.

[12] Blavatsky, Helena. 2016. The Voice of the Silence. Scotts Valley, CA: CreateSpace Independent Publishing Platform.

[13] Gebra, Fernando. 2012. "O ritual esotérico no poema "Iniciação" de Fernando Pessoa", IPOTESI, 16(2): 47-61.

[14] Pessoa, Fernando. 1942. Poesias. Lisboa: Editoral Ática.

[15] Pessoa, Fernando. 1985. Fernando Pessoa e a Filosofia Hermética - Fragmentos do espólio (Org. Yvette Centeno). Lisboa: Editorial Presença.

[16] Lind, Georg. 1981. Estudos sobre Fernando Pessoa. Lisboa: Imprensa Nacional Casa da Moeda.

[17] Centeno, Yvette. 2003. Fernando Pessoa: Magia e Fantasia. Lisboa: Edições Asa.

[18] Simões, João. 2011. Vida e obra de Fernando Pessoa. Lisboa: EditoraBonecos Rebeldes.

[19] Pessoa, Fernando. s/data. Escritos Ocultistas: Rituais, Em: Arquivo Pessoa: Obra Édita. http://Arquivopessoa.net/textos/.

[20] Pessoa, Fernando. 1986. Escritos Íntimos, Cartas e Páginas Autobiográficas. Lisboa: Publicações EuropaAmérica.

[21] Costa, Dalila. 1978. O Esoterismo de Fernando Pessoa. Porto: Editores Lello\&Irmãos.

[22] Coyné, André. 2011. Regards sur Fernando Pessoa. Milan: ÉditionsArchè.

[23] Luna, Jayro. 2005. A Chave Esotérica da Mensagem de Fernando Pessoa: Abordagem Numerológica, Astrológica e Cabalística. São Paulo: Epsilon Volantis.

[24] Martins, Paulo. 2019. "The influence of Indian Philosophy and Spirituality in the Work of Fernando Pessoa: Some perspectives", Journal of Advances in Social Sciences and Humanities, 5(4):692-702. 
[25] Pessoa, Fernando. 1979. Sobre Portugal - Introdução ao Problema Nacional.(Recolha de textos de Maria Isabel Rocheta e Maria Paula Morão. Introdução organizada por Joel Serrão.). Lisboa: Ática. [1ªpublicaçãoem 14-04-1929, "O Fado e a Alma Portuguesa”, Notícias Ilustrado, 2a série, no 44, Lisboa].

[26] Mota, Pedro da. 2016. "A Caminho do Oriente: Apontamentos de Pessoa sobre Teosofia e Espiritualidade da Índia”. Pessoa Plural, 9:230-251.

[27] Coelho, Maria. 2010. Mensagens de Mensagem (de Fernando Pessoa). Tese de Mestrado em Estudos Portugueses, Faculdade de Ciências Sociais e Humanas da Universidade Nova de Lisboa.

[28] Pessoa, Fernando. 2007. Message (Mensagem) (Translated by Jonathan Griffin). Bristol: Shearman Books.

[29] Ryan, Bartholomew. 2017. “Aplicando as expressões de Pessoa 'Nonregionalism' e 'Indefinitenessof Soul' ao Cosmopolitismo Radical e à RacialidadePluritópica”. Casa Fernando Pessoa/CFP-Actas: 92-103.

[30] Jacinto, Conceição e Lança, Gabriela. 1999.A Análise do Texto Mensagem. Porto: Porto Editora.

[31] Soares, Maria Almira. 2000.Para uma leitura de Mensagem de Fernando Pessoa. Lisboa: Editorial Presença.

[32] Rita, Annabela. 2017. "Emergência da «Hora» Pessoana”. Faculdade de Letras de Lisboa/CLEPUL:28-46.

[33] Real, Miguel. 2013. Mensagem de Fernando Pessoa. Lisboa: Edições Parsifal.

[34] Camocardi, Elêusis. 1996. Mensagem: História, Mito, Metáfora. São Paulo: Editora Arte\&Ciência.

[35] Rita, Annabela e Freitas, Rui e Anes, José e Mota, Pedro. 2019. Fernando Pessoa: Hermetismo, Gnose e Alquimia, Em: III Jornadas de História, Filosofia Hermética e Património Simbólico (In: III Day’s Journey of History, Hermetic Philosophy and Symbolic Heritage). Livraria-Galeria Municipal Verney, Oeiras.

[36] Centeno, Yvette. 1990. O pensamento esotérico de Fernando Pessoa. Lisboa: Publicações Culturais Engrenagem.

[37] Centeno, Yvette. 1985. Fernando Pessoa - O Amor, a Morte, a Iniciação. Lisboa: Edições Regras do Jogo.

[38] Lopes, Teresa. 1990. Pessoa por conhecer. Lisboa: Editorial Estampa. Volume II.

[39] Lourenço, Eduardo. 2000. Pessoa Revisitado. Lisboa: Editora Gradiva.

[40] Freitas, Ana e López, Pablo e Sousa, Rui e al. 2017. Pessoa livre, Em: Congresso Internacional sobre Fernando Pessoa (In: Fernando Pessoa InternationalCongress). Fundação Calouste Gulbenkian (Org. Casa Fernando Pessoa).

1-Freitas, Lima de. 2006. Porto do Graal. Lisboa: Ésquilo Editores.

2- Signs are a mathematical construction (like the calendar) that takes into account the precession of Hipparchus equinoxes.

3 - Jung, Carl. 2000. Os arquétipos e o inconsciente colectivo, Tomo I, Em: Obra Completas de C.G. Jung. Lisboa: Editora Vozes, Volume IX.

4,5 - English translation is my responsibility.

6 - Jung, Carl. 2000. Aion: Estudo sobre o simbolismo do si-mesmo, Tomo II, Em: Obra Completas de C.G. Jung. Lisboa: Editora Vozes, Volume IX.

7 - English translation is my responsibility.

8 - Jung, Carl. 2011. Psicologia e Alquimia. Em: Obra Completas de C.G. Jung. Lisboa: Editora Vozes, Volume XII.

9- Jung, Carl. 2012. Sincronicidade. Lisboa: Editora Vozes.

10 - English translation is my responsibility.

11 - Spiller, Jan. 1997. Astrology for the Soul. New York: Bantam Books.

12 - English translation is my responsibility.

13 - Feather, Robert. 2005. The Secret Initiation of Jesus at Qumran. Rochester, VT: Bear \& Company.

14 - The "initiation of the Birth" of Jesus took place in Bethlehem. Bethlehem is formed by the words "Beit" (House) and "Lehem" (Bread); that is, the "House of Bread" (in Arabic and Hebrew), as an element fundamental to Life, ie, which the Philosophies of India call "Anna Maya Kosha". Symbolically, the "birth initiation" represents the "union of the personality with the Soul/Self".

15- The symbolism of the "Bread" is something that recurs in the Life of Jesus. For example, it is described, before the beginning of His Mission, in the Gospel (Mt 4: 1-4): «He fasted forty days and forty nights and, finally, he was hungry. The tempter came and said, "If You are the Son of God, order these stones to become bread." Jesus replied, "It is written: Man does not live by bread alone, but by every word that comes out of the mouth of God.» Then, already during His Mission on Earth, he is described in the Gospel (Mt 15, 34-38): «Jesus asked them: "How many loaves do you have?" "Seven", they answered, "and some small fish". Then, Jesus pitied the crowd, multiplied the bread and the fish, and gave them to the disciples to distribute to the crowd... 
Now, those who ate were four thousand men, not counting women and children. "». English translation is my responsibility.

16- Jesus' "initiation of Baptism" occurred after 30 years, representing the "symbolic importance of time" for the "transmutation" of desires and concrete thinking; that is, what the Indian Philosophies call "Kama Maya Kosha" and "Mano Maya Kosha", respectively. Symbolically, the "initiation of Baptism" represents the "union of the Soul/Self with the Spirit" and is described in the Gospel passage (Jn 3: 1-5): «Jesus answered him: "Truly, truly, I say to you, Whoever is not born again cannot see the Kingdom of God". Nicodemus said to him, "How can a man be born when he is old? Will you be able to enter your mother's breast a second time and be born again?" Jesus replied: "Truly, truly, I say to you, Unless one is born of water and the Spirit, he cannot enter the Kingdom of God. What is born of the flesh is flesh, and what is born of the Spirit is spirit..."». English translation is my responsibility.

17 - Bailey, Alice. 1985. Iniciação Humana e Solar. Rio de Janeiro: Fundação Cultural Avatar. English translation is my responsibility.

$18,19,20,21,22,23,24,25,26,27$ - English translation is my responsibility.

28- Pavri, Pestanji. 2015. Teosofia explicada. Adyar: Mar de Teosofia.

29 - Martins, Paulo. 2009. A Mecânica Quântica e o pensamento de Amit Goswami. Tese de Doutoramento, Faculdade de Ciências e Tecnologia da Universidade Nova de Lisboa. FCT-UNL.

30, 31, 32, 33- English translation is my responsibility.

34 - The OM is formed by the union of the letters "A" (corresponds to Brahma-The Creator), "U" (corresponds to Vishnu-The Sustainer), "M" (corresponds to Shiva-The Renovator) - as a symbol of Trimurti. The OM (referred to in the Vedas) is called "pranava" because it is the primordial power from which all creation originates, and the Mandukya Upanishad describes the previous three letters as corresponding to the "states of consciousness", respectively, awakening, dreams and deep sleep. For example, see Martins, Roberto de. 2013. O indizível no pensamento Indiano: a sabedoria que ultrapassa os conceitos. In: Religião, a herança das crenças e as diversidades de crer. Santos, João (org.). Campina Grande: Editora da Universidade Federal de Campina Grande, pg. 85-102.

35- The Koan is a dialogue with aspects that are not understandable for the reason, with the objective of taking the individual to the "connection" with the Self or true Self, as a primary factor in the creation process. For example, see Wenger, Michael e Prieto, José. 2013. Penetrante Compasion: Cincuente Koan Contemporaneos. Madrid: Miraguano Ediciones.

36- English translation is my responsibility.

37 - Costa, Frei Alcindo.1981. Bíblia Sagrada, Jo 1:1-18. Fátima: Difusora Bíblica.

38 - Wells, Herbert. 1984. História Universal. Carnaxide: Livros do Brasil. 3 Volumes.

39, 40, 41, 42- English translation is my responsibility.

43 - Martins, Paulo.2020. Fátima and the values of contemporary society: An essay, Icon of Faith, International Journal of Interdisciplinary Scientific Research, 11(6):37-40.

44 - The Mensagem is related to the expression "Mens agitat molem" ("the Spirit moves matter") of the Aeneid; that is, the existence of a "universal principle" (or Conscious One) from which all material existence comes.

45 - English translation is my responsibility.

46 - Wilkins, William. 2013. Hindu Mythology. Calcutta: Rupa Pubications Private Limited.

47 - In the "Miracle of the Roses", the "transformation of Bread into Roses" was highlighted, as symbols of the sources of Life. The "Bread" linked to the "Spiritual Birth" [In Notes 14 and 15 this reference is made], while the "Rose and the Cross" linked to "Baptism" [In Note 16 this reference is made], and this miracle makes the link between two distinct "Initiatic stages". English translation is my responsibility.

48 - For a study on the symbolism of the "Rose linked to the Sacred", please see the documentary on de Fernandes, Joaquim and Toldy, Teresa and Martins, José et al. 2017. The Faces of Fátima. History Channel. 49 - Vyasa, Krishna-Dwaipayana. 1993. Bhagavad-Gita. Calcutta: Willian Walker Atkinson.

50 - English translation is my responsibility 


\section{AUTHOR'S BIOGRAPHY}

Paulo NunoMartins, is a Chemical Engineer from Instituto Superior Técnico, University of Lisbon and a PhD in History and Philosophy of Science from Faculty of Sciences and Technology, New University of Lisbon. The author has studied for four years Oriental languages and culture (Indian, Chinese, Japanese) and he is currently a researcher at International Center for Transdisciplinary Research, France (CIRET),Transdisciplinary Center for Consciousness Studies, University Fernando Pessoa of Oporto(CTEC-UFP) and Interuniversity Center for History of Science and Technology, New University of Lisbon, Portugal (CIUHCT-UNL).

Citation:Paulo Nuno Martins. "Raphael Baldaya and Fernando Pessoa: The Search for a Common Universal Source of Inquiry between Symbology and Poetry" International Journal of History and Cultural Studies (IJHCS). vol 6, no. 3, 2020, pp. 21-30. doi: DOI: https://doi.org/ 10.20431/2454-7654.0603003.

Copyright: () 2020 Authors. This is an open-access article distributed under the terms of the Creative Commons Attribution License, which permits unrestricted use, distribution, and reproduction in any medium, provided the original author and source are credited. 